\title{
Characteristics and Evolution of China's Industry-University-Research Collaboration to Promote the Sustainable Development: Based on Policy Text Analysis
}

\author{
Xiaojie Yao *, Yuan Hu *, Huaping Gong and Dongyou Chen \\ School of Management, Nanchang University, Nanchang 330031, China; ghping1964@163.com (H.G.); \\ cdy63@163.com (D.C.) \\ * Correspondence: xjieyao@126.com (X.Y.); hyuan@ncu.edu.cn (Y.H.)
}

check for updates

Citation: Yao, X.; Hu, Y.; Gong, H.; Chen, D. Characteristics and Evolution of China's Industry-University-Research Collaboration to Promote the Sustainable Development: Based on Policy Text Analysis. Sustainability 2021, 13, 13105. https://doi.org/ $10.3390 /$ su132313105

Academic Editor: Antonio

Messeni Petruzzelli

Received: 19 October 2021

Accepted: 22 November 2021

Published: 26 November 2021

Publisher's Note: MDPI stays neutral with regard to jurisdictional claims in published maps and institutional affiliations.

Copyright: (c) 2021 by the authors. Licensee MDPI, Basel, Switzerland. This article is an open access article distributed under the terms and conditions of the Creative Commons Attribution (CC BY) license (https:/ / creativecommons.org/licenses/by/ $4.0 /)$.

\begin{abstract}
Collaborative innovation is an effective way to realize national innovation and sustainable development. The Chinese government has issued a series of Industry-University-Research (IUR) policies and regulations in recent decades to effectively promote the development of national scientific and technological innovation. Exploring the characteristics and evolution of IUR collaborative policy is critical for the healthy development of IUR and subsequent policy formulation. In this study, we collected IUR policy texts at the national level of China from 1992 to 2020 as the research object. On the basis of policy tool theory, a three-dimensional analysis framework of "Policy tool-Policy theme-Evolution stage" was constructed and studied using content analysis and social network analysis methods. Through the quantitative statistical analysis, we find that China's IUR policies have experienced four development stages. Among all policy tools, the supply-side IUR ones are sufficient, whereas demand-side policy tools are insufficient. The service system policy theme is lacking relative to other themes. In addition, the application of information technology (IT) policies is prominent. Therefore, we suggest optimizing the policy structure in combination with social characteristics and strengthening the establishment of service system innovation. Enhancing the role of IT to promote innovation policies is also recommended.
\end{abstract}

Keywords: Industry-University-Research; collaborative innovation; policy text; policy theme; quantitative analysis

\section{Introduction}

During the era of rapid development facilitated by the knowledge economy, scientific and technological innovation has become essential to improving national competitiveness [1,2]. Nowadays, in facing societal problems that are complex and changeable, resource-sharing and coordination have become inevitable choices for different innovation subjects $[3,4]$. Collaborative innovation can effectively improve innovation efficiency by integrating resources and avoiding risks [5]. Industry-University-Research (IUR) collaboration is an important means to raise the sustainable development of national scientific and technological innovation through sharing innovation resources and combining the advantages of enterprises, universities, and scientific research institutions [6]. On the one hand, scientific research and university can provide enterprises with technical and innovative talents. On the other hand, the resources obtained from industrial application can benefit universities and research [7]. Therefore, the IUR collaboration is currently becoming a major strategy to improve the ability for national innovation and to realize the sustainable development for most countries in the world [8].

Internationally, the early model of IUR collaboration is the Manhattan Plan implemented by the United States during World War II. Subsequently, the United States, Britain, Japan, and other countries continued to promote the model of IUR collaboration and achieved remarkable results in the improvement of national scientific and technological 
innovation and the transformation of scientific and technological achievements [9]. In China, the IUR strategy began in the early 1980s, which focused on the management of collaborative innovation subjects of enterprises, universities, and scientific research institutes [10]. However, no professional IUR terms were developed in the national policies. In 2019, after the Fourth Plenary Session of the 19th Central Committee of the Communist Party of China, the IUR collaborative innovation system has basically formed with enterprises as the main body, market orientation, and deep integration of IUR.

The policies of IUR collaboration can effectively improve national innovation and development [11]. In recent years, China's IUR policies have usually appeared in major national socioeconomic development plans and science and technology development plans [12]. As a developing country, China's science, technology, and economy are undergoing a rapid development. In March 2021, the Chinese 14th Five-Year Plan (2021-2025) and the Long-Range Objectives to 2035 mentioned that China will further optimize the resource allocation and sharing of scientific research institutes, universities, and enterprises to improve the overall efficiency of the innovation chain. According to the 2020 global innovation index, China ranks 14 th and is the only middle-income country in the top 30 in the world. The national IUR policies first motivate the deep integration of science, technology, and economy, and then promote economic development $[13,14]$.

The Chinese government pays increasing attention to promote the sustainable innovative development of the national economy and society through the coordinated development policies. However, the scientific and technological innovation level of China still lags behind some developed countries $[15,16]$. To secure the actual IUR policy environment toward sustainability in China and explore the current limitations or deficiencies of IUR policies, analyzing the law and characteristics of China's IUR policies over recent decades is necessary.

An increasing number of scholars focus on IUR collaboration policies to explore the characteristics of China's IUR policies. Existing studies on China's IUR policies are classified into two categories: qualitative and quantitative analyses. On the one hand, scholars have been mainly conducting qualitative studies for a long time, such as the policy comparison analysis between China and other countries, to learn the experience of other national policies [17]. Specific supporting policies related to IUR collaborative innovation are also considered insufficient to support IUR collaboration, such as education, finance, and taxation [18]. On the other hand, an increasing number of studies attempt to utilize various research methods to conduct quantitative research on China's IUR policies [19], analyzing and summarizing the current IUR collaborative innovation policy paradigm and related issues [20]. Policy keywords and their relationships are explored through bibliometric analysis [21]. In addition, social network analysis is developed to track themes and policy focus changes of the scientific and technological innovation policies in different periods [22]. In recent years, the quantitative analysis of policy text has been widely adopted. With the development of policy science, collaborative innovation policies at the national or regional level are widely explored using policy tool analysis [23]. The policy objectives, policy objects or policy themes are effectively explored [24]. Therefore, a detailed study of analyzing the characteristics of policy tools of IUR collaboration will optimize the IUR strategy in China and effectively promote national innovation and sustainable development.

In sum, existing IUR policies mostly utilize qualitative analysis, focusing on summaries of policy experience and reflecting on problems, that cannot scientifically and accurately identify the characteristics and guidance of the policies. Although some research on the policies has performed analysis from a quantitative perspective, the use of policy tools, policy content, and policy evolution characteristics in China as a whole has not been systematically explored.

In this study, three research questions will be answered:

RQ1: What are the characteristics of the policy tools in China's IUR policies?

RQ2: What are the characteristics of the policy themes? 
RQ3: What are the evolution characteristics of China's IUR policies?

China's IUR policy texts at the national level in the past 30 years are taken as the sample. On the basis of policy tool theory, we employ content analysis and social network analysis methods to conduct quantitative analysis on policy texts. The study aims to first explore the characteristics of China's IUR policies, and then provide advice for their formulation and the promotion of national innovation and sustainable development in the future.

\section{Materials and Methods}

\subsection{Conceptual Framework}

A reasonable policy analysis framework is helpful to explore the government's policymaking characteristics in public policies [25]. However, the separate policy tool dimension cannot adequately reflect the comprehensive characteristics of a policy system [26]. Besides, the policies will work simultaneously in time and space. Therefore, a three-dimensional (3D) framework was constructed, as illustrated in Figure 1, to analyze the characteristics of China's IUR policies in the past 30 years. This conceptual framework includes policy tool, policy theme, and policy evolution stage. Through the 3D framework analysis, we can not only clarify the use characteristics of the policy tools and policy theme contents of IUR policies but also the time evolution characteristics and the policy development trend.

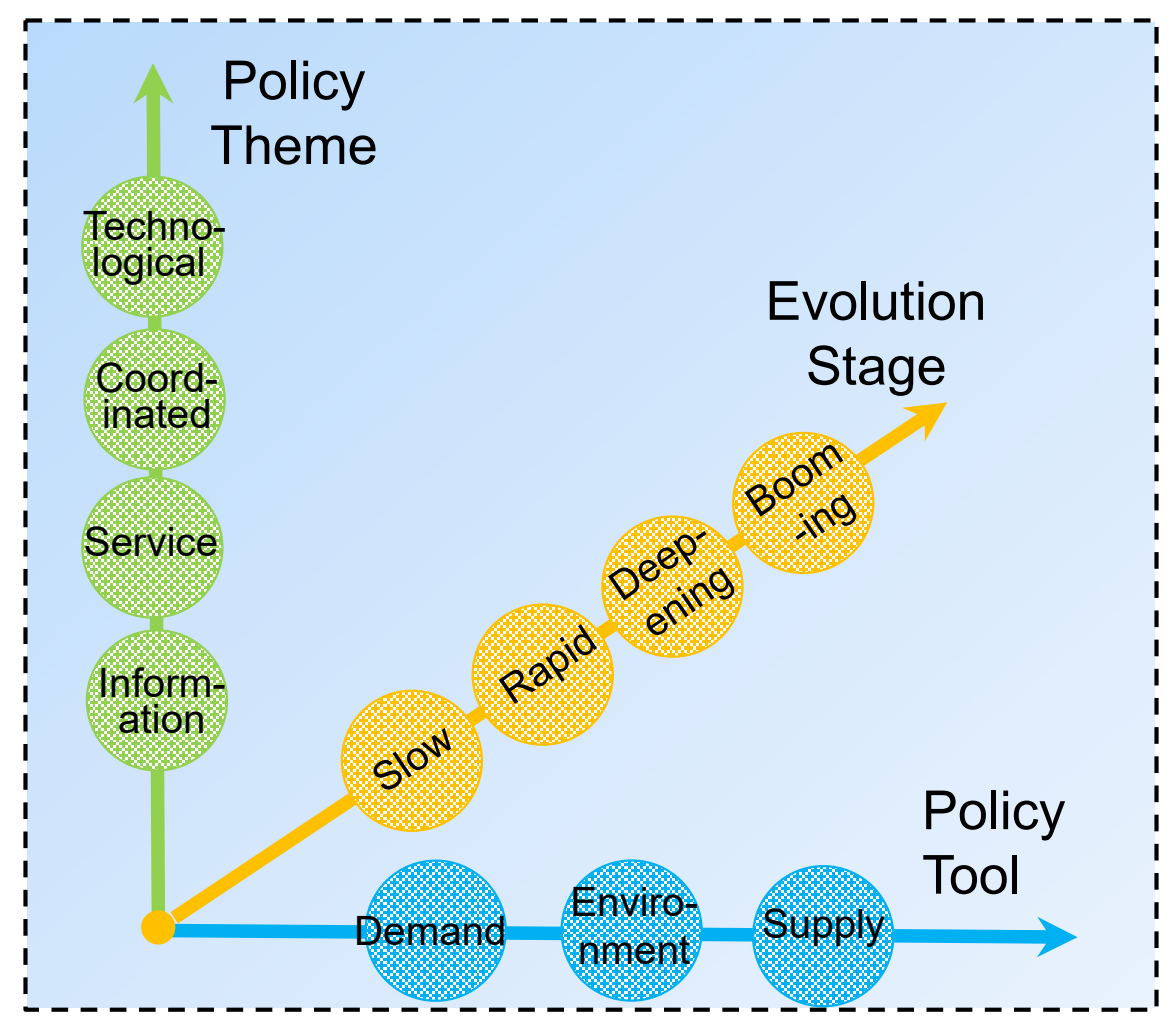

Figure 1. The conceptual framework of China's IUR policies.

\section{(1) Policy Tool}

Policy tool widely appeared in the 1980s and has become an important topic in the field of policy science and public administration [27]. Policy tool theory focuses on the achievement of policy objectives, an important means for the government to promote and implement policy measures [28]. By identifying the choice of policy tools for China's national IUR, we can clarify what means the government adopts to achieve the policy objectives of national sustainable and innovative development. 
According to the findings of Rothwell [29], policy tools are divided into supply-side, environment-side, and demand-side tools. On the basis of relevant research $[25,26]$, we summarize the three sides of China's IUR policies, which are as follows:

Supply side refers to when the government plays a direct role in IUR-coordinated innovation by the support and supply of information, talent, technology, and capital.

Environment-side means that the government indirectly affects IUR collaborative innovation development through the macro strategic deployment of regulations or plans.

Demand-side refers to when the government enacts continuous support measures by reducing the uncertain factors in IUR development.

The three sides are classified into different contents to describe the policy tools in further detail. The sub-category of policy tools and their specific meanings are shown in Table 1.

Table 1. Classification of policy tools and meaning descriptions.

\begin{tabular}{|c|c|c|c|}
\hline \multicolumn{2}{|c|}{ Policy Tool } & \multirow{2}{*}{$\begin{array}{c}\text { Meaning Description } \\
\begin{array}{c}\text { Providing talent guarantee through talent training, talent } \\
\text { introduction, talent development planning. }\end{array}\end{array}$} & Ref. \\
\hline \multirow{4}{*}{ Supply side } & Talent team & & \multirow{4}{*}[30,31]{} \\
\hline & Capital investment & $\begin{array}{l}\text { The direct financial support through R\&D investment, } \\
\text { science and technology funds, financial subsidies etc. }\end{array}$ & \\
\hline & Infrastructure & $\begin{array}{l}\text { Infrastructure construction of innovation platform and } \\
\text { innovation base, including National University Science } \\
\text { Park, science and technology enterprise incubator. }\end{array}$ & \\
\hline & Information service & $\begin{array}{l}\text { Providing public information services for enterprises, } \\
\text { scientific research institutes and other innovation subjects } \\
\text { through information collection, open data or information } \\
\text { technology support. }\end{array}$ & \\
\hline \multirow{4}{*}{ Environment-side } & Credit financing & $\begin{array}{l}\text { Providing financial support by means of credit preference, } \\
\text { loan discount, venture capital or relaxing financing terms. }\end{array}$ & \multirow{4}{*}[32,33]{} \\
\hline & Regulatory control & $\begin{array}{l}\text { Establishing a stable and favorable market environment } \\
\text { using enterprise systems and technical standards to } \\
\text { regulate intellectual property rights, benefits distribution } \\
\text { and facilitate technology transfer. }\end{array}$ & \\
\hline & Tax preference & $\begin{array}{l}\text { Tax measures to stimulate market vitality including } \\
\text { enterprise tax relief, subsidies, or deferred payment etc. }\end{array}$ & \\
\hline & Strategy measures & $\begin{array}{l}\text { Reward and punishment measures to stimulate IUR } \\
\text { innovative development of market. }\end{array}$ & \\
\hline \multirow{4}{*}{ Demand-side } & Government procurement & $\begin{array}{c}\text { Financial funds to purchase relevant required } \\
\text { technologies, products and services for scientific and } \\
\text { technological collaborative innovation. }\end{array}$ & \multirow{4}{*}[17,34]{} \\
\hline & International cooperation & $\begin{array}{l}\text { International exchanges and cooperation between } \\
\text { enterprises and scientific research institutions for } \\
\text { promoting collaborative development. }\end{array}$ & \\
\hline & Service outsourcing & $\begin{array}{l}\text { Government's R\&D plans distributed to enterprises or } \\
\text { IUR collaboration organizations. }\end{array}$ & \\
\hline & Demonstration project & $\begin{array}{l}\text { IUR innovation demonstration base, demonstration } \\
\text { projects or major scientific demonstration projects. }\end{array}$ & \\
\hline
\end{tabular}

\section{(2) Policy Theme}

A text theme is a collection of knowledge units that reflects the implicit semantic structure [35]. Theme discovery can help us analyze large-scale information and find the main content and information in the text. In this study, policy theme is defined as the application content of IUR policies, including the main content themes and the roles played in the national IUR policies. Combined with the existing research results [36], 
China's IUR policy themes are classified into four categories: collaborative development, technological innovation, service system, and information technology (IT). Policy themes and their specific meanings are described in Table 2.

Table 2. Policy themes and descriptions.

\begin{tabular}{cc}
\hline Policy Theme & Meaning Description \\
\hline Collaborative development & $\begin{array}{c}\text { Integrating the advantageous resources of different innovation subjects } \\
\text { to promote the development of national innovation through the national } \\
\text { IUR collaborative innovation system and innovation strategy. }\end{array}$ \\
\hline Technological innovation & $\begin{array}{c}\text { Drawing up a scientific plan, talent plan, or the transformation of } \\
\text { scientific and technological achievements to accelerate the development } \\
\text { of scientific and technological innovation. }\end{array}$ \\
\hline Service system & $\begin{array}{c}\text { Providing services for IUR innovative development through the } \\
\text { corresponding supportive construction, evaluation or consultation of } \\
\text { third-party service institutions etc. }\end{array}$ \\
\hline Information technology & $\begin{array}{c}\text { Providing information disclosure or information exchange platforms for } \\
\text { the acquisition, processing and analysis of information data, to support } \\
\text { data and information of the IUR innovation development. }\end{array}$ \\
\hline
\end{tabular}

\section{(3) Evolution Stage}

The government can effectively realize the policy objectives when the policies are in accordance with the development period in a country [39]. To further clarify the evolution characteristics of policy tools and themes, we study the policies' development and change at different stages. On the basis of existing research on IUR collaboration [40] and important national development strategies, China's IUR collaboration policies can be divided into four development stages: slow development stage (1992-2005), rapid development stage (2006-2010), deepening development stage (2011-2015), and booming development stage (2016-2020). Policy evolution stages and their meanings are described in Table 3.

Table 3. Policy evolution stages and descriptions.

\begin{tabular}{|c|c|c|c|}
\hline Evolution Stage & Time Span & Meaning Description & Ref. \\
\hline Slow development & (1992-2005) & $\begin{array}{l}\text { Through the reform of science and technology systems, the } \\
\text { government guided the combination of scientific research institutes, } \\
\text { universities, and enterprises to stimulate the vitality of IUR } \\
\text { collaboration, and began to explore the development of cooperative } \\
\text { innovation under the Chinese situation. }\end{array}$ & \\
\hline Rapid development & $(2006-2010)$ & $\begin{array}{l}\text { The state implemented independent innovation and encouraged } \\
\text { the IUR innovative development through various ways, which } \\
\text { have driven the rapid development of IUR collaboration, such as } \\
\text { the IUR strategic alliance. }\end{array}$ & {$[39,40]$} \\
\hline Deepening development & (2011-2015) & $\begin{array}{l}\text { The state took innovation-driven development and innovation } \\
\text { ability as the starting point and paid attention to the in-depth } \\
\text { integration of IUR. Moreover, the diversified innovation carriers } \\
\text { provided more opportunities for further developing IUR. }\end{array}$ & \\
\hline Booming development & $(2016-2020)$ & $\begin{array}{l}\text { New-generation information technology, such as Internet and big } \\
\text { data, provided support for the sharing and opening of innovation } \\
\text { subjects, and led to IUR prosperity and development. }\end{array}$ & \\
\hline
\end{tabular}

\subsection{Research Methods}

\section{(1) Content Analysis}

Content analysis, as a method of text mining, takes qualitative problems as the starting point and conducts quantitative statistical analysis to draw research conclusions, which can avoid the interference caused by subjective consciousness [41]. The research steps of 
content analysis method can generally be divided into the following: first raising research questions, sampling, selecting analysis units, establishing analysis categories; and then quantitative processing and calculation, including coding, classification, and quantitative statistics of analysis units; and finally, the interpretation and testing of the analysis results. Text coding, as an important technology of content analysis, involves quantitative text analyzed by classifying and labeling the content of the analysis unit [42]. On the basis of text content analysis, this study performs a quantitative analysis of the national IUR policy texts in China.

\section{(2) Social Network Analysis}

Social network analysis method, derived from graph theory, focuses on the interactive relationship among individuals through quantitative indicators $[43,44]$. The knowledge relationship can be clearly explored using a visual knowledge map. In the study of text mining, the keyword co-occurrence network can effectively present the relationship between characteristic members and the location structure among keywords [45]. When two keywords appear in the same text, this shows a certain internal relationship between the two words. When the frequency of co-occurrence is more than expected, the relationship and distance between keywords are closer than usual. In this research, policy theme categories can be expressed through the combination of the keywords. To explore the relationships of keywords in China's IUR policy texts, a keyword co-occurrence matrix is constructed, and the network relationship is measured and analyzed.

\subsection{Research Materials}

IUR policies refer to various laws, regulations, and policies formulated in China [46]. To encourage and promote collaborative innovation, the government reasonably allocates the innovative resources of all parties to enterprises, universities, scientific research institutions, and various scientific and technological service institutions [47]. In this work, we take the national policy text closely related to the IUR collaborative innovation policies in China as the analysis sample, including departmental rules and administrative regulations. The data were collected from the policy and regulation platform. To ensure data effectiveness, the obtained policy texts were manually identified and screened, and texts irrelevant or less relevant to the research were filtered and deleted. Finally, 502 policy texts were obtained. The specific search strategies are the following:

Platform: Chinese government law data bank and China Law retrieval system, which provides a large number of legal policies; for further comprehensiveness, the data were supplemented from the websites of the State Council and its subordinate ministries and commissions.

Search Expression: keywords such as "industry university research", "scientific research institutions", "collaborative innovation", "innovation alliance", and "scientific and technological innovation" were retrieved.

Policy Years: Policies issued from 1992 to 2020.

\subsection{Text Encoding}

The text encoding was divided into two steps. First, we chose the sentences related to IUR from the sample as the analysis units. Second, the units were marked by coding the policy chapter to form coding numbers. As presented in Table 4, the analysis units were classified to each dimension of policy tools, topics, and development stages. On the basis of the above coding principles, 1864 policy clauses were obtained. 
Table 4. Example of text coding of China's IUR policies.

\begin{tabular}{|c|c|c|c|c|c|c|}
\hline $\begin{array}{c}\text { Policy Name } \\
\text { (Original Link) }\end{array}$ & Analysis Unit & Encoding & Policy Tool & $\begin{array}{l}\text { Policy } \\
\text { Theme }\end{array}$ & $\begin{array}{c}\text { Evolution } \\
\text { Stage }\end{array}$ & Ref. \\
\hline $\begin{array}{l}\text { National Guideline on Medium- } \\
\text { and Long-Term Program Science } \\
\text { and Technology Development } \\
\text { (2006-2020) (http:/ / www.gov.cn/ } \\
\text { gongbao/content/2006/content_ } \\
\text { 240244.htm, accessed on } \\
\text { 7 Feberaury 2006) }\end{array}$ & $\begin{array}{l}\text { Technology platforms } \\
\text { established by the IUR } \\
\text { collaboration of key } \\
\text { industries will be } \\
\text { supported first in the } \\
\text { national infrastructure } \\
\text { construction of science } \\
\text { and technology. }\end{array}$ & $84-5$ & Infrastructure & $\begin{array}{l}\text { Service } \\
\text { system }\end{array}$ & $\begin{array}{c}\text { Rapid } \\
\text { development }\end{array}$ & \\
\hline $\begin{array}{l}\text { The 13th Five-Year Plan on } \\
\text { National Informatization Program } \\
\text { (http:/ / www.gov.cn/zhengce/ } \\
\text { content/2016-12/27/content_51 } \\
\text { 53411.htm, accessed on } \\
\text { 27 December 2016) }\end{array}$ & $\begin{array}{l}\text { Accelerating the } \\
\text { formulation of standards } \\
\text { and patent layout related } \\
\text { to the new generation of } \\
\text { information technology. }\end{array}$ & $403-4$ & $\begin{array}{l}\text { Regulatory } \\
\text { control }\end{array}$ & $\begin{array}{l}\text { Information } \\
\text { technology }\end{array}$ & $\begin{array}{c}\text { Booming } \\
\text { development }\end{array}$ & {$[33,48]$} \\
\hline $\begin{array}{l}\text { Proposals for Formulating the 14th } \\
\text { Five-Year Plan (2021-2025) for } \\
\text { National Economic and Social } \\
\text { Development and the Long-Range } \\
\text { Objectives through the Year } 2035 \\
\text { (http://www.gov.cn/zhengce/20 } \\
20-11 / 03 / \text { content_5556991.htm, } \\
\text { accessed on } 29 \text { October 2020) }\end{array}$ & $\begin{array}{l}\text { Encouraging enterprises } \\
\text { to increase R\&D } \\
\text { investment, and giving } \\
\text { more tax preference to } \\
\text { enterprises investing in } \\
\text { basic research. }\end{array}$ & $495-3$ & Tax preference & $\begin{array}{l}\text { Technological } \\
\text { innovation }\end{array}$ & $\begin{array}{c}\text { Booming } \\
\text { development }\end{array}$ & \\
\hline
\end{tabular}

\section{Results}

\subsection{Distribution of Policy Texts}

The distribution of year, department, and effectiveness levels of policies issued was analyzed statistically, as displayed in Figure 2, to clarify the overall situation of China's IUR policies. From 1992, such policies have spanned approximately 30 years. The time distribution of policy texts is shown in Figure $2 \mathrm{a}$ to study their change trend and characteristics. As seen from Figure 2a, the cumulative number of the China's IUR collaborative policies showed an overall upward trend from 1992 to 2020 . However, the annual number of the policies revealed four peak growth rates in 2001, 2006, 2011, and 2016, that is, every five years. This regular pattern is only consistent with the National Five-Year Plan, suggesting that IUR policies are consistent with the national socioeconomic development strategy. Therefore, IUR policies in the future need to be designated and issued at effective points in time. In detail, for the peak at 2006, the Chinese government begun to pay attention to IUR collaborative innovation on a national strategic level. By 2011, the number of issued policies reached a new peak, with the entry into the next Five-Year Plan. In 2016, the 13th Five-Year Plan for national scientific and technological innovation was issued, which is a guide for China to become an innovative country. Subsequently, the IUR collaborative innovation policies of China entered a new development period, and new features with Chinese characteristics were gradually formed.

The policy text distribution of policy issuing departments was counted in Figure $2 b$ to explore the government departments providing policy guarantee for the national IUR development. The policies issued by the Ministry of Science and Technology and the Ministry of Education account for $21 \%$ and 19\%, respectively, which are much higher than those of other departments. This result suggests that the IUR development direction in China is guided by the two departments mentioned above, followed by the National Development and Reform Commission. Evidently, more governments are involved in the designation of IUR policies. The accounting ratios of the State Council, the General Office of the State Council, the Ministry of Industry and Information Technology, and the Ministry of Finance are more than $7 \%$, indicating that these departments also provide governmental guarantee to promote the innovative development of IUR. However, policy promulgation remains insufficient. Therefore, the policymakers of China's IUR take the 
Ministry of Science and Technology and the Ministry of Education as the core, combined with other departments to jointly promote IUR development.

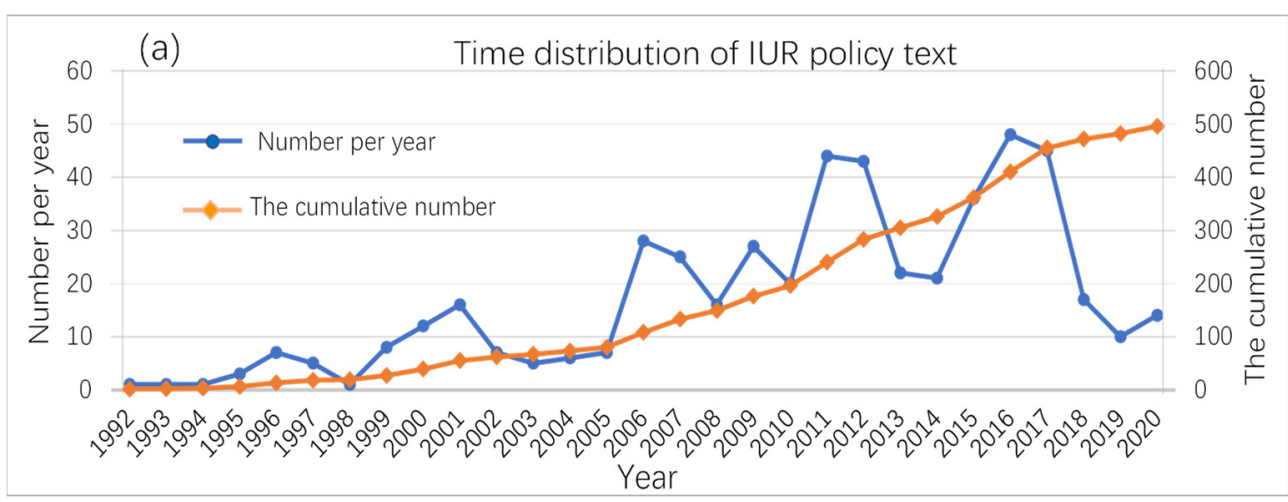

Text distribution of issuing department Text distribution of effectiveness level

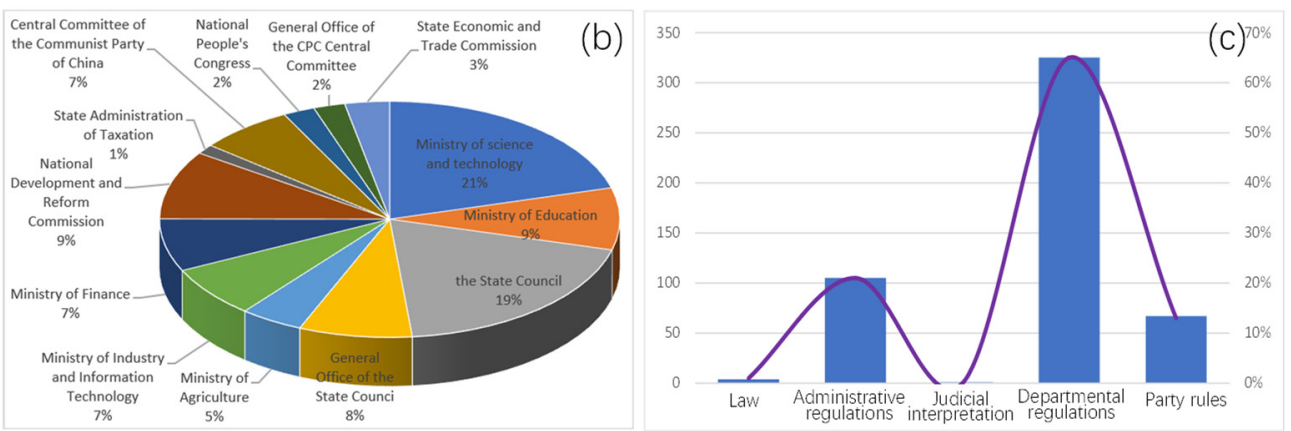

Figure 2. The text distribution according to time (a); issuing department (b); and effectiveness level (c) of IUR policies in China.

Policy laws and regulations at different levels have different degrees of effectiveness. In China, laws are deliberated and adopted by the National People's Congress at the highest level of effectiveness. Administrative regulations are formulated by the State Council, and the effectiveness is second to the laws. Departmental rules, which are effective within a certain range, are generally formulated by ministries and commissions under the State Council. The levels of judicial interpretation and group regulation are relatively low. Innerparty regulations formulated by party organizations are an important guarantee of national laws. The statistical analysis of IUR policy effectiveness levels was performed, as illustrated in Figure 2c, to clarify the degree of importance ascribed by the state to IUR development. The number of departmental rules accounts for the largest proportion, suggesting that the national IUR policies cover many fields, such as the Ministry of Technology, the Ministry of Industrial Information, and the Ministry of Agriculture. The government actively promotes the implementation of innovative development in this field. Ministries and Commissions are the main departments for the formulation of IUR policies. The administrative regulations take second place, indicating that the State Council is the main body for issuing documents and makes an overall plan for the implementation of IUR policies. However, the laws and judicial interpretations are short. Therefore, strengthening the effectiveness of the laws relating to IUR policies and putting them into practice in via policy interpretation are necessary.

\subsection{Keyword Co-Occurrence Network}

Keywords represent the core content of IUR policy texts. Keyword extraction and frequency statistics are helpful in quickly exploring the key content information of IUR policy texts. Therefore, we used Python to extract and obtain 28 high-frequency keywords of IUR policies. The keyword co-occurrence analysis is effective in studying the relationships in policy texts. Therefore, the co-occurrence network of high-frequency keywords 
was employed to reveal policy themes and their implicit relationship with China's IUR policies, as displayed in Figure 3. In the network, the large node representing a highfrequency keyword shows that the network centrality is high. In addition, the lines reflect the co-occurrence relationship among keywords. The thick connecting line means a strong correlation. In Figure 3, the keywords of IUR collaboration, scientific and technological innovation, innovation ability, innovation system, and collaborative innovation are not only in the center of the network but also have a strong correlation with other keywords, suggesting that they play a key role in the network of China's IUR development. The overall IUR relationship network indicates that China's IUR policies constitute a complex interaction network. Moreover, the continuous interaction among different keywords promotes the development of IUR collaborative innovation in China.

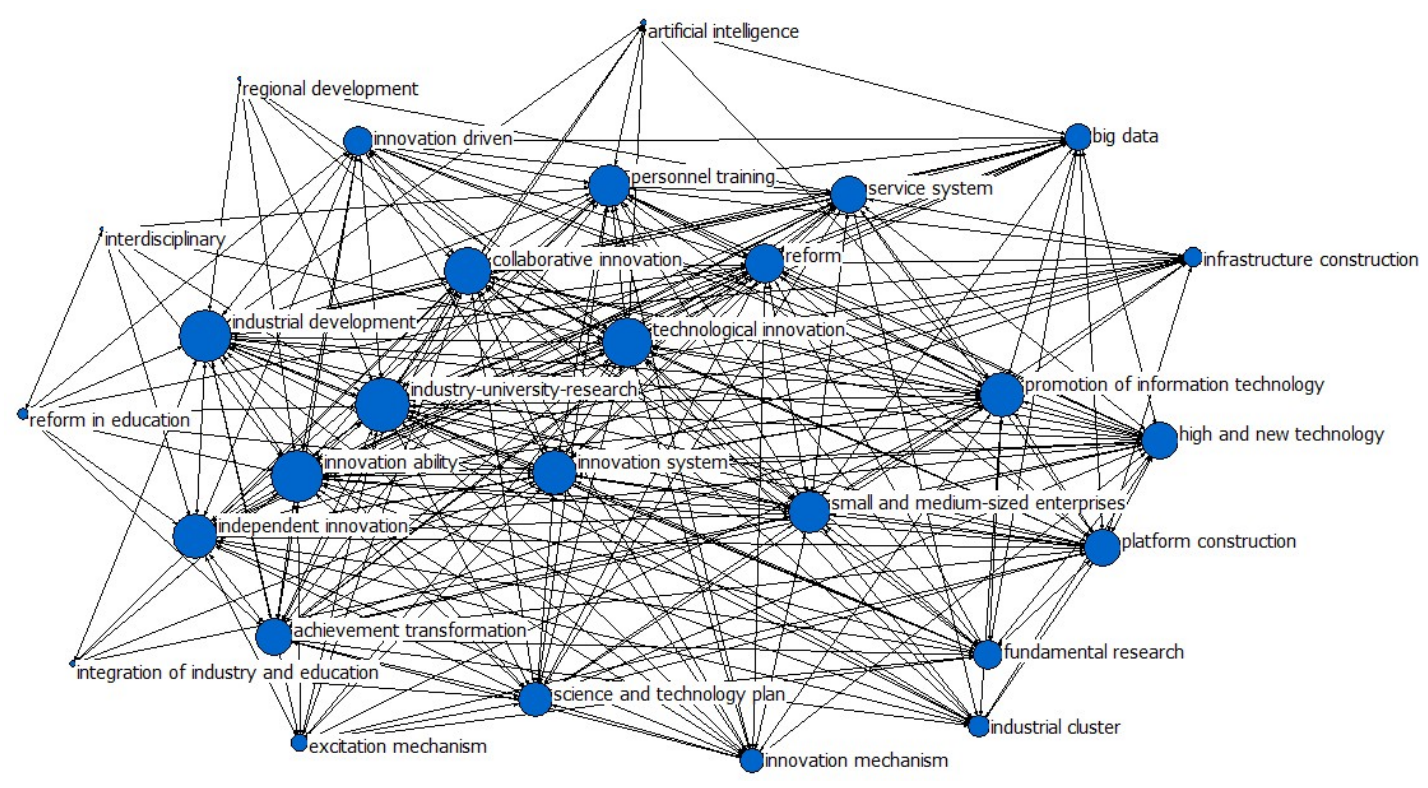

Figure 3. The co-occurrence network of keywords on IUR policies.

\subsection{Quantitative Analysis at Different Dimensions}

\subsubsection{Policy Tools Dimension Analysis}

The frequency of policy tool types is shown in Figure 4 to clarify the use characteristics of different policy tools. Among the three types of policy tools, the proportions of environment-side (58\%) and supply-side (33\%) tools are much larger than the $9 \%$ of demand-side tools, indicating that the government makes full use of environment and supply policies, whereas demand-side policies are few.

Specifically, in the application of supply-side policies, the ratio of talent team is the largest $(30 \%)$, whereas infrastructure construction $(24 \%)$ and capital investment $(18 \%)$ account for relatively smaller proportions. This result suggests that the government should reasonably expand effective investments, make good use of development financial instruments, and attract additional private capital to participate in the construction of projects in key fields. In environment-side policies, strategic measures and regulatory controls, respectively, account for $45 \%$ and $34 \%$ and are widely used by the government, whereas the use of tax-preference policies is low. This finding indicates that tax policies, such as tax relief and subsidies, need further strengthening to stimulate market vitality. Among demand-side policies, the largest proportion is the demonstration project at $42 \%$, and the proportion of service outsourcing is very small (only 10\%). To solve the mismatch between the demand side and the supply side of public services, government public service outsourcing can improve the quality of public services by purchasing public services from the market. This strategy is widely used in Western countries. However, at present, the demand-oriented policy of IUR service outsourcing in China is seriously insufficient. 
Therefore, the government should strengthen service outsourcing in the future. In short, the above results indicate that different types of policy tools are used unevenly, and the government should further increase the relative use of IUR policy tools to promote national innovation and development.

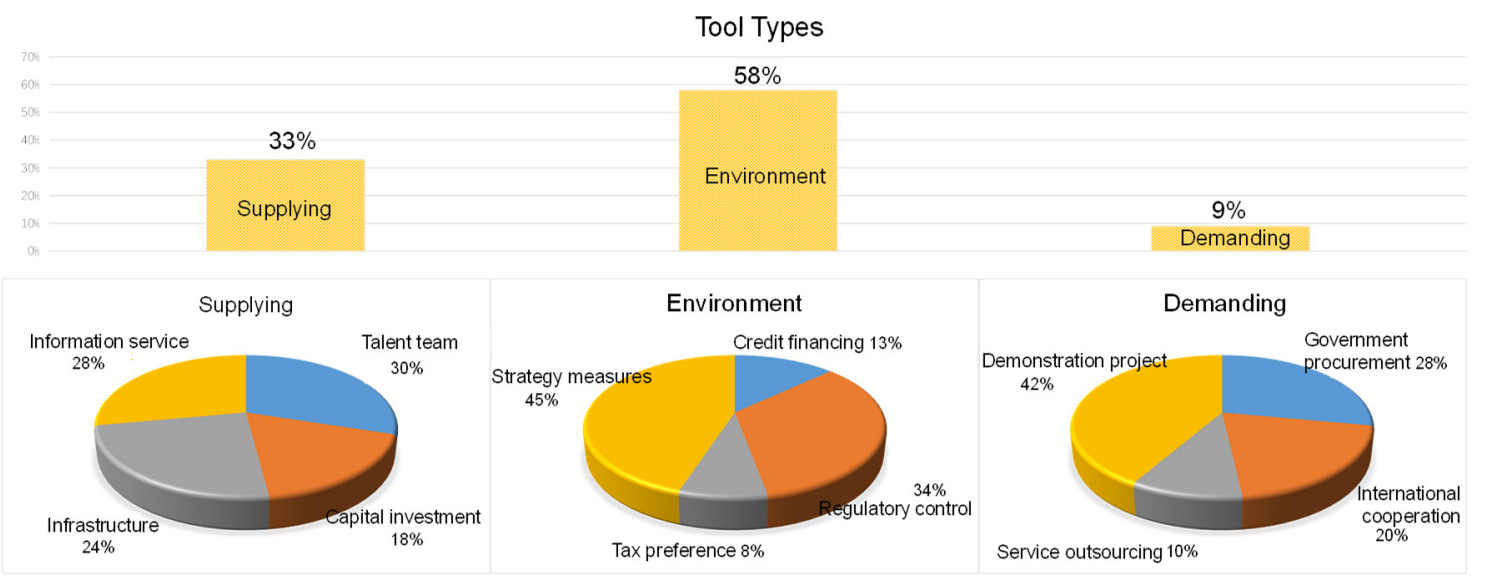

Figure 4. The frequency statistics of policy tools.

\subsubsection{Policy Themes Dimension Analysis}

The frequency statistics of policy themes are shown in Figure 5 to present the focus of China's IUR government policies. In general, collaborative development and scientific and technological innovation are utilized at high frequencies, whereas the application frequencies of IT and service system are low. Thus, the Chinese government pays extra attention to the design of collaborative development and scientific and technological innovation policies to promote IUR development. On the contrary, the issued policies on service system and information are still insufficient. The service system is becoming increasingly important in promoting IUR development. Moreover, IT has attracted enough attention from the state, which has become a key element of the collaborative innovation of IUR. Therefore, further strengthening the supporting policies of service system and IT is necessary.

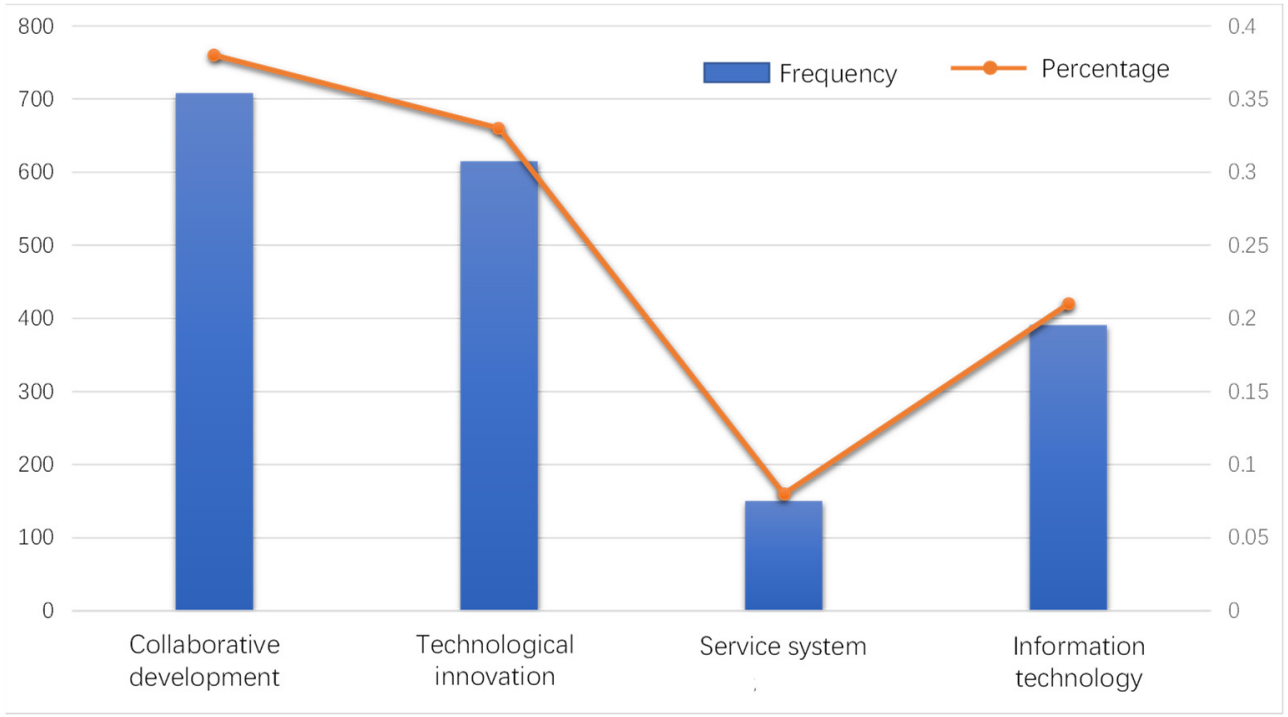

Figure 5. The frequency statistics of policy themes.

\subsubsection{Time Dimension Evolution Analysis}

The stage evolution analysis was performed to effectively explore the change characteristics of policy tools and policy themes in different periods. The use frequency of policy 
tools at different stages is shown in Figure 6. The total frequency of policy tools exhibits an obvious increasing trend. The frequency is less than 200 during the slow development period, and more than 700 during the booming development stage. In contrast to the continuously decreasing proportion of environment-side tools, the ratios of supply-side and demand-side tools gradually increase with IUR development, suggesting that the government first focuses on supply-side policies, paying attention to the construction of the policy environment. However, demand-side policies are becoming increasingly important to the continuous development in the booming development stage.

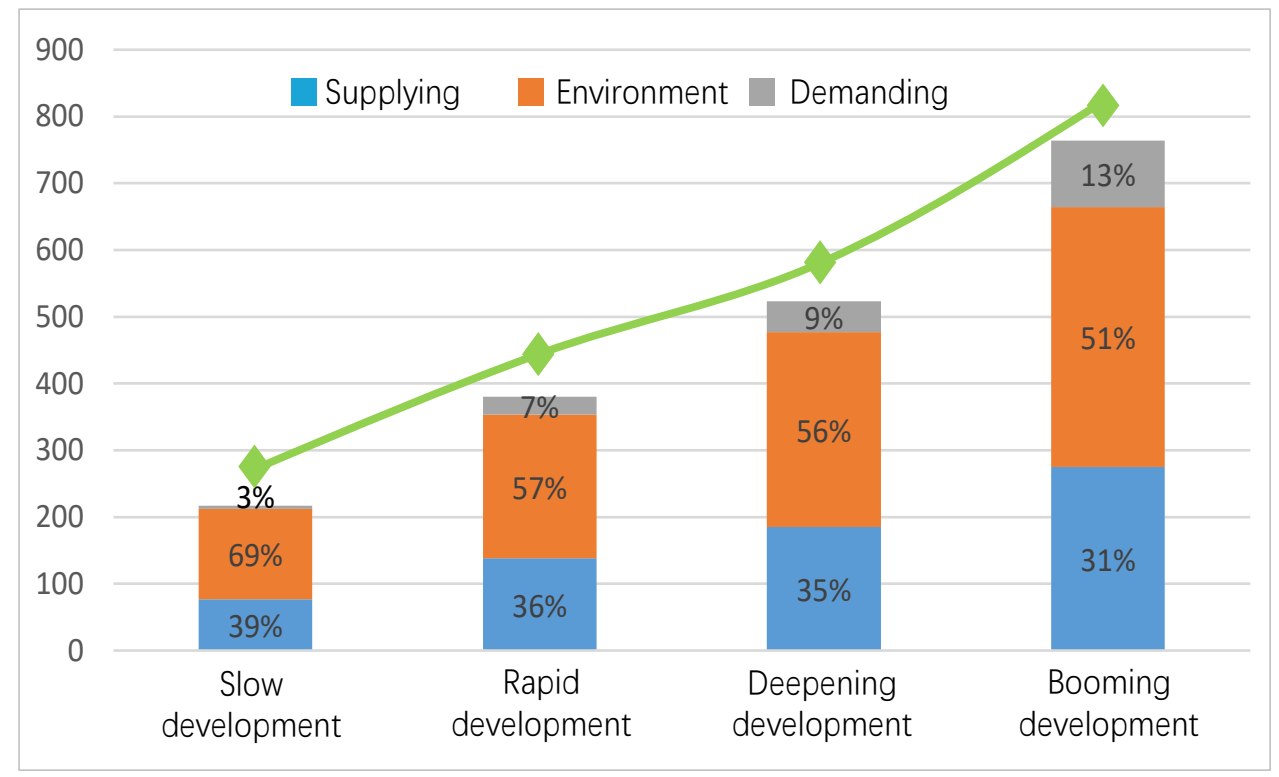

Figure 6. The stage evolution of policy tools.

The use of policy themes in different stages is illustrated in Figure 7 to explore the evolution characteristics of policy themes. The application frequencies of the four policy themes all exhibit an increasing trend with IUR development. The development trend of scientific and technological innovation and service system is steady. However, the use of service system policy themes is low during all periods. Policies on scientific and technological innovation and service system show no sudden increase during the different periods. The result suggests that the application of service system policy is insufficient. Therefore, the government should pay extra attention to IUR public innovative services and increase IUR policies related to service system themes to meet the needs of innovation and development.

In detail, during the slow development period, the policy theme frequencies of collaborative development, technological innovation, service system, and IT are all low. IUR policies begin to rise during the subsequent rapid development period and deepening development period, suggesting that the state actively implements innovation policies. During the rapid development period, the policies take "independent innovation" as the main focus, emphasizing independent innovation, talent training, and technological innovation organization construction. After the Plan for Improving Innovation Ability of Universities (Chinese 2011 Plan) was issued, collaborative innovation has become the core concept of the national implementation of scientific and technological innovation. The collaborative innovation policy on IUR has been developed rapidly.

Note that the rates of increase for cooperative development and IT intensify during the booming period. Compared with the deepening development period, collaborative innovation and service system increase by factors of four and three, respectively. During the booming development period, the policy themes of collaborative development and IT rapidly reach $436(29.5 \%)$ and 199 (13\%), respectively. The new-generation IT will effectively promote the IUR collaborative and national innovation and development. 


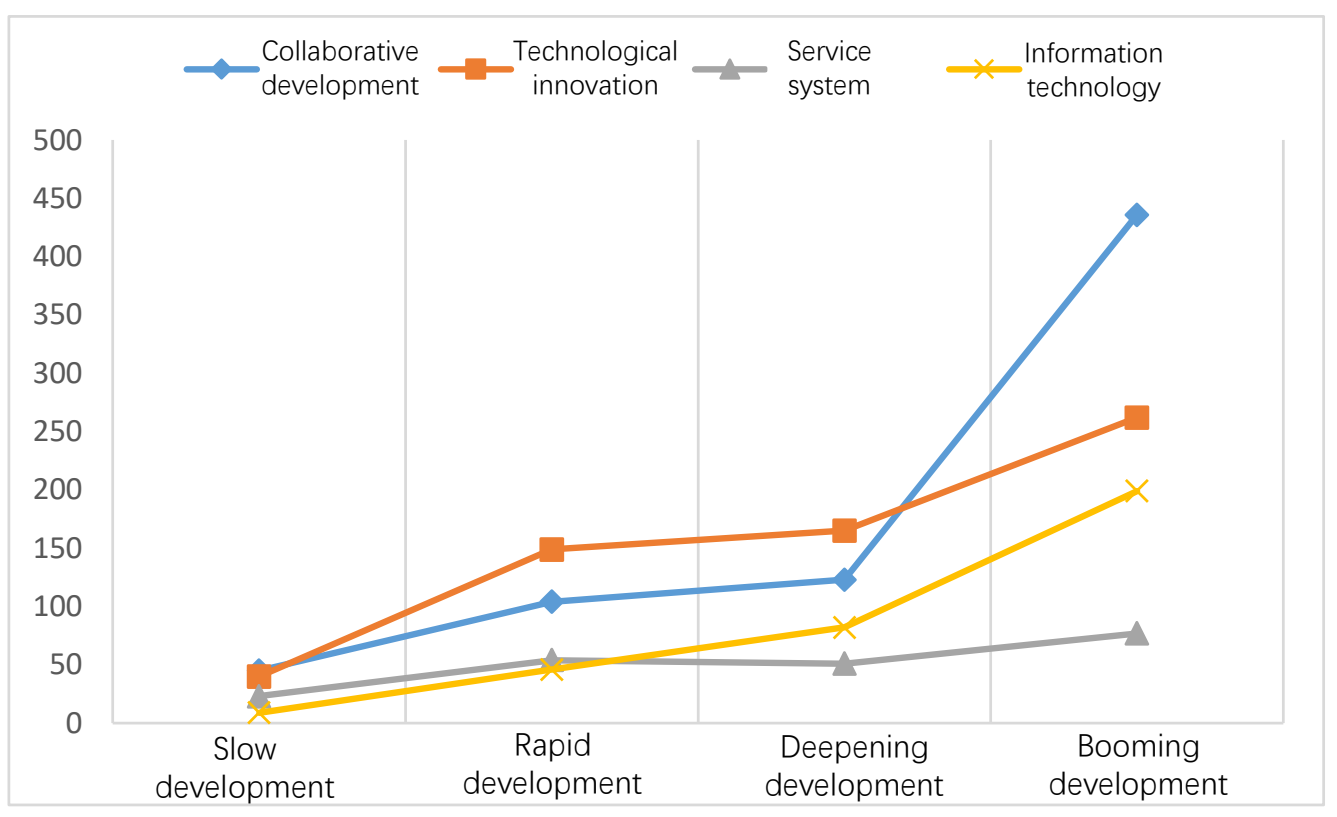

Figure 7. The stage evolution of policy themes.

\section{Discussion}

\subsection{Characteristics of Application of IUR Policy Tools}

IUR has supply-side, environment-side, and demand-side policy tools. The results of the analysis of policy tools reveal that different sides are unevenly distributed. Supply-side and environment-side policies are fully used, whereas demand-side policies are insufficient.

On the one hand, China's IUR policies attach importance to supply-side policies. For a long time, supply-side policies, such as talent team construction and capital, have been widely used [49], suggesting that our government pays attention to providing important basic guarantees through the active supply of human, financial, material, and technical support. Meanwhile, the frequent use of strategic measures reflects the continuous implementation of macro guidance by the government. As for environment-side tools, the government strengthens market supervision by formulating laws, regulations, industry standards, and other policies [50]. However, some key problems still lack specific and effective regulatory measures, such as ownership of intellectual property rights and transformation of scientific and technological achievements [51]. The use of tax incentives, credit financing, and regulatory control is still less, suggesting that these measures do not attract enough attention from the government. To promote innovation and development, major developed countries, such as Britain and the United States, have basically formed a series of tax-preference systems, such as a low tax rate and tax relief. Sound tax policies can give full consideration to the important role of incentivizing and mobilizing the enthusiasm of all collaborative subjects.

On the other hand, demand-side policies are relatively lacking. Policies such as service outsourcing and government procurement are also still lacking. China, as a developing country restricted by the level of economic development, has long emphasized supply-side policies to promote faster and better economic development, resulting in overcapacity and other problems [52]. Demand-side policies are related to the social demand side through market stimulation. From the socioeconomic transformation perspective, demand-based policies show great potential and effectiveness.

\subsection{Characteristics of the Use of IUR Policy Themes}

The policy themes of collaborative development, scientific and technological innovation, service system, and IT interact to cooperatively promote the level of national innovation and development. As far as the policy theme categories are concerned, the use of public service policies is relatively weak. IT has become key to promote the innovative 
development of IUR [53]. Theme categories affect and interact with one another to jointly improve collaborative innovation and development. The four interrelated theme categories play different roles to promote China's IUR development. The roles of China's IUR policy themes are shown in Figure 8. Collaborative development pays extra attention to the construction of innovation drive that is the source power of IUR; scientific and technological innovation is the core content of IUR; service system is the basic guarantee of IUR; IT is the supporting condition for the realization of IUR [54,55]. Therefore, the government should maintain the balance of various policy themes and enhance interrelated policies, so that it can play a better role in collaboration.

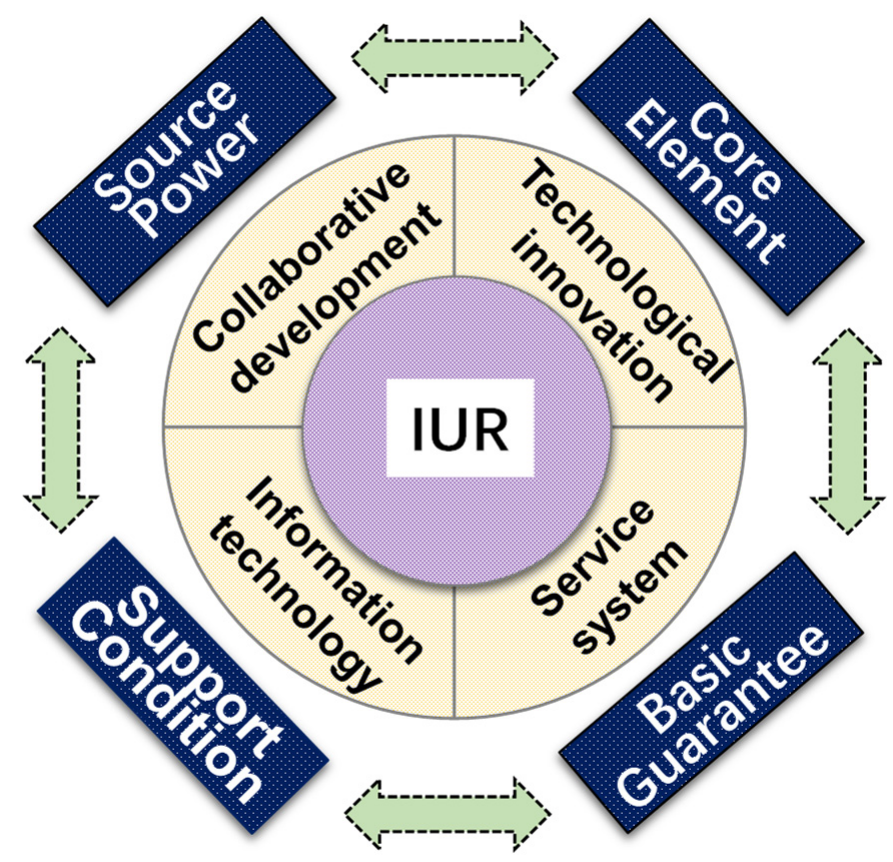

Figure 8. The roles of China's IUR policy themes.

However, the application of service system policies is insufficient. Overall, service policies are imperfect and cannot meet the needs of national collaborative innovation and development. For example, the science and technology intermediary service system is inadequate [56]; it has only one function and lacks intermediary institutions for specific industries. The policy of "Several opinions on accelerating the development of science and technology service industry" was issued in 2014 by the State Council, which put forward key tasks to promote the development of the science and technology service industry, but the specific implementation policy still requires further development. Authoritative evaluation of institutional performance and the effect of policy implementation is still lacking. Mature and effective IUR performance evaluation institutions and mechanisms must be established, which regularly publish performance evaluation reports on innovation performance and can provide a basis for scientific decision making. Therefore, it is necessary to enhance IUR service policies in various ways, such as establishing diversified intermediary service organizations to improve service functions.

\subsection{Evolution Characteristics of China's IUR Policies}

IUR policies evolve along with the national strategy. The time evolution of IUR policies embodies the position of the national development strategy, especially the National FiveYear Plan for national socioeconomic development. The Five-Year Plan, as an important part of the Chinese national economic plan, sets out the goals and directions of national economic development. The corresponding relationship between the evolution stages of IUR policies and the national strategy is presented in Table 5. Evidently, IUR policies are an important force to promote the Five-Year Plan. 
Overall, the orientation of China's IUR development is consistent with the evolving national scheme of the Strategy of Invigorating the Country through Science, Technology, and Education (1995), the Independent Innovation Strategy (2006), the Innovation-Driven Development Strategy (2011), and the Information Development Strategy (2016). In the early stage of the 1980s, China began to accelerate the cooperation between universities and industry, mainly through the field of education. In the middle of the 1990s, since the implementation of the science and education strategy to rejuvenate the country, the combination of IUR has been considered an important way to build a national innovation system. After 2005, the government emphasized the improvement of the national independent innovation capability through the combination with IUR, demonstrating that IUR collaborative innovation has been raised to the national strategic level.

China's IUR policies, as an important part of the national innovation system, are in line with the major national policies in different periods. Meanwhile, the coordination of IUR continues to deepen the integration. In the future, the formulation and implementation of the national IUR policies must be carried out under the guidance of the national socioeconomic development strategy to accelerate the innovative development of the national economy and society.

Table 5. The relationship between IRU development stage and national strategy in China.

\begin{tabular}{ccc}
\hline Evolution Stage & National Five-Year Plan & National Strategy \\
\hline Slow development & $\begin{array}{c}\text { The last four years of 8th Five-Year } \\
\text { Plan, 9th Five-Year Plan and 10th } \\
\text { Five-Year Plan }\end{array}$ & $\begin{array}{c}\text { Strategy of invigorating the country } \\
\text { through science and education }\end{array}$ \\
\hline Rapid development & 11th Five-Year Plan & Independent innovation strategy \\
\hline Deepening development & 12th Five-Year Plan & Innovation-driven development strategy \\
\hline Booming development & 13th Five-Year Plan & Information development strategy \\
\hline
\end{tabular}

Demand-side policies are increasing because of the evolution of IUR policy tools. The proportion of the three types of policy tools changes with the time evolution of IUR policies. The frequencies of environment-side and supply-side policies during the prosperity and development periods are markedly decreased compared with those during the slow development period. Meanwhile, the proportion of demand-side policy tools is gradually increasing, illustrating that the national policy is constantly adjusted and optimized according to the market demand.

The establishment of China's socialist market economic system has experienced a long process. The national economic development has been dominated by supply-side policies for a long time. After 2003, national policies concerning the improvement of the socialist market economic system demonstrated that China entered a new period of improving the system. The government started attaching importance to allocating resources through the autonomy, competitiveness, and effectiveness of the market subjects. Demand-based policies began to increase significantly. In the last decade, the collaborative innovation among enterprises, education, and scientific research has deepened. Therefore, policymakers should further enhance demand-side policies to better stimulate the vitality of the cities and meet the market demand.

In the past decade, IT innovation has become an important engine for enhancing national scientific and technological innovation in a new development era [59]. In 2006, after the "National Informatization Development Strategy (2006-2020)" was promulgated, IT has been constantly infiltrating many fields, such as agriculture, medical and health care, and education, which has substantially changed innovation behaviors and methods and improved innovation efficiency. China continuously uses IT to accelerate the process of IUR collaborative innovation. For example, in 2017, the IUR alliance of IT new engineering was established to meet the development needs of China's new economy models. IT is changing the market structure and competition rules, introducing a new way for 
enterprises to develop market opportunities and realizing the collaborative innovation of IUR. In recent years, the new-generation IT, such as big data, artificial intelligence, cloud computing, blockchain, virtual/augmented reality, and mobile Internet (5G), has greatly improved innovation efficiency [60]. Since 2020, the COVID-19 epidemic has been bringing new changes through production and learning and accelerating the pace of digitalization, networking, and the intellectualization of enterprises and education. Blockchain technology can help form a national IUR innovation chain, which can meet the market demand, by establishing the information sharing platform of government, enterprise, and scientific research.

Compared with traditional industries, the new-generation IT industry has the characteristics of high technical content, a long industrial chain, and a high requirement for the comprehensive quality of employees. The IUR should employ the new-generation IT to realize the deep cooperation and efficient collaborative innovation under the complex situations of multiple stages, multi-cooperation subjects, and multi-cooperation modes. However, the new-generation IT has not been comprehensively implemented in the IUR collaboration of China. The National Informatization Development Strategy for 2006-2020, issued in 2006, clearly expressed that the nation would realize independent innovation in key areas of IT. The fifth-generation IT provides an opportunity for IUR collaborative innovation but also faces great challenges. Therefore, the government should give further attention to the leading role of IT and then promote the in-depth integration of IT within industry and education.

\section{Conclusions}

This work investigated the overall application of the Chinese government's IUR policy tools and themes. It also explored the evolution of national policies in different periods, especially the characteristics of the current policy application. Our research has contributed to a better understanding of the Chinese government's governance experience and strategies. The findings can help to provide guidance to policymakers in implementing future IUR policies to improve the national innovation and sustainable development.

The supply-side and environment-side policies of China's IUR are fully used, but the demand-side policies are insufficient. In the interrelated system of different policy themes, service policies are insufficient. According to the characteristics of policy time evolution, we find that the evolution of IUR policies adequately reflects the national strategy. Demand-side policies on the evolution of IUR policy tools are gradually increasing, and IT is becoming an important driving force.

IUR collaboration has become an important means of national and social innovation and sustainable development. However, China's innovation policies still need to establish a more systematic and effective IUR collaborative innovation policy system. On the basis of our findings, we present pieces of advice to improve the application of IUR policies. The government should strengthen demand-based policy tools and give full consideration to policy synergy. Moreover, the service system and policies need to increase to make up a greater proportion of IUR policies. The application of new-generation IT can highlight innovation efficiency.

In addition, we collected China's IUR policies only at the national level and did not consider the policy texts in individual regions. With this limitation, we cannot further understand the situations and characteristics of IUR policies in specific regions and the implementation effect of the national IUR policies. Future research should collect more textual data, including national and regional data, and explore their characteristics and application effects in detail.

Author Contributions: Conceptualization, X.Y. and Y.H.; methodology, X.Y., Y.H. and H.G.; formal analysis, X.Y.; data curation, X.Y.; writing-original draft preparation, X.Y.; writing-review and editing, Y.H., H.G. and D.C.; visualization, Y.H.; super-vision, Y.H. All authors have read and agreed to the published version of the manuscript. 
Funding: This work was supported by the National Social Science Foundation of China (20BTQ056); the Social Science Planning Foundation of Jiangxi Province (19TQ03).

Institutional Review Board Statement: Not applicable.

Informed Consent Statement: Not applicable.

Data Availability Statement: The data presented in this study are available on request from the corresponding authors.

Conflicts of Interest: The authors declare no conflict of interest.

\section{References}

1. Papa, A.; Chierici, R.; Ballestra, L.V.; Meissner, D.; Orhan, M.A. Harvesting reflective knowledge exchange for inbound open innovation in complex collaborative networks: An empirical verification in Europe. J. Knowl. Manag. 2021, 25, 669-692. [CrossRef]

2. Fini, R.; Perkmann, M.; Ross, J.M. Attention to Exploration: The Effect of Academic Entrepreneurship on the Production of Scientific Knowledge; Social Science Electronic Publishing: Rochester, NY, USA, 2021; Available online: https:/ / ssrn.com/abstract=3768333 (accessed on 23 January 2021).

3. Hampel, C.; Perkmann, M.; Phillips, N. Beyond the lean start-up: Experimentation in corporate entrepreneurship and innovation. Innov. Organ. Manag. 2020, 22, 1-11. [CrossRef]

4. Martín-Rubio, I.; Andina, D. University knowledge transfer offices and social responsibility. Adm. Sci. 2016, 6, 20. [CrossRef]

5. Wang, B.J.; Zhu, R. Evaluation on policy efficacy and effect of industry-university-research cooperative innovation. Soft Sci. 2019, $33,30-36$.

6. Atta-Owusu, K.; Fitjar, R.D.; Rodriguez-Pose, A. What drives university-industry collaboration? Research excellence or firm collaboration strategy? Technol. Forecast. Soc. Chang. 2021, 173, 121084. [CrossRef]

7. Mian, S.H.; Salah, B.; Ameen, W.; Moiduddin, K.; Alkhalefah, H. Adapting universities for sustainability education in industry 4.0: Channel of challenges and opportunities. Sustainability 2020, 12, 6100. [CrossRef]

8. Hemmert, M.; Bstieler, L.; Okamuro, H. Bridging the cultural divide: Trust formation in university-industry research collaborations in the US, Japan, and South Korea. Technovation 2014, 34, 605-616. [CrossRef]

9. Leydesdorff, L.; Carley, S.; Rafols, I. Global maps of science based on the new Web-of-Science categories. Scientometrics 2013, 94, 589-593. [CrossRef]

10. Zhu, G.L.; Zang, Y.; Chen, K.H. The evolution of the international research on university industry collaboration. Stud. Sci. Sci. 2015, 33, 1669-1686.

11. Gao, X.; Guo, X.; Guan, J. An analysis of the patenting activities and collaboration among industry-university-research institutes in the Chinese ICT sector. Scientometrics 2014, 98, 247-263. [CrossRef]

12. Lu, J.L.; Zhang, S.J. Evolutionary development of innovation policy: Framework, transformation and China's policy agenda. China Soft Sci. 2019, 40, 23-35.

13. Oztemel, E.; Gursev, S. Literature review of Industry 4.0 and related technologies. J. Intell. Manuf. 2020, 31, 127-182. [CrossRef]

14. Wit-de Vries, E.; Dolfsma, W.A.; Windti, H.J.; Gerkema, M.P. Knowledge transfer in university-industry research partnerships: A review. J. Technol. Transf. 2019, 44, 1236-1255. [CrossRef]

15. Vick, T.E.; Robertson, M. A systematic literature review of UK university-industry collaboration for knowledge transfer: A future research agenda. Sci. Public Policy 2018, 45, 579-590. [CrossRef]

16. Acs, Z.J.; Audretsch, D.B.; Lehmann, E.E.; Licht, G. National systems of innovation. J. Technol. Transf. 2017, 42, 997-1008. [CrossRef]

17. Salami, R.; Soltanzadeh, J. Comparative analysis for science, technology and innovation policy; Lessons learned from some selected countries (Brazil, India, China, South Korea and South Africa) for other LDCs like Iran. J. Technol. Manag. Innov. 2012, 7, 211-227. [CrossRef]

18. Gao, D.Y.; Zhang, Q.Q.; Su, L.F. The relationship between the revitalization of German first-class universities and the industryuniversity-research cooperation and its enlightenment. China Econ. Educ. Rev. 2020, 5, 92-106.

19. Colombo, M.G.; Grilli, L.; Murtinu, S. R\&D subsidies and the performance of high-tech start-ups. Econ. Lett. 2011, 112, 97-99.

20. Fagerberg, J. Innovation policy: Rationales, lessons and challenges. J. Econ. Surv. 2017, 31, 497-512. [CrossRef]

21. Tan, J.; Fu, H.Z.; Ho, Y.S. A bibliometric analysis of research on proteomics in Science Citation Index Expanded. Scientometrics 2014, 98, 1473-1490. [CrossRef]

22. Cao, X. Global networks and domestic policy convergence: A network explanation of policy changes. World Politics 2012, 64, 375-425. [CrossRef]

23. Xu, P.; Luo, F. Textual and quantitative research on science, technology and innovation policies in China from the perspective of policy tools. Stud. Sci. Sci. 2020, 38, 826-833.

24. Lin, K.C.; Shyu, J.Z.; Ding, K. A cross-strait comparison of innovation policy under industry 4.0 and sustainability development transition. Sustainability 2017, 9, 786. [CrossRef]

25. Zhu, G.L.; Yang, X.W.; Jiang, Z.P. A study for the changes of collaborative innovation policy based on three-dimensional framework of level-goal-tool. Sci. Technol. Prog. Policy 2018, 35, 110-117. 
26. Ma, X.B.; Li, Y.; Qin, C.X.; Liu, W.; Liu, H.L.; Lu, X.J. Research on the policy system of opening public information resources based on three-dimensional analysis framework. Manag. Rev. 2020, 32, 143-154.

27. Grant, W. Policy instruments in the common agricultural policy. West Eur. Politics 2010, 33, 22-38. [CrossRef]

28. Shen, L.; He, B.; Jiao, L.; Song, X.; Zhang, X. Research on the development of main policy instruments for improving building energy-efficiency. J. Clean. Prod. 2016, 112, 1789-1803. [CrossRef]

29. Rothwell, R. Reindustrialization and technology: Towards a national policy framework. Sci. Public Policy 1985, 12, 113-130. [CrossRef]

30. Canhoto, A.I.; Quinton, S.; Jackson, P.; Dibb, S. The co-production of value in digital, university-industry R\&D collaborative projects. Ind. Mark. Manag. 2016, 56, 86-96.

31. Cantner, U.; Graf, H.; Herrmann, J.; Kalthaus, M. Inventor networks in renewable energies: The influence of the policy mix in Germany. Res. Policy 2016, 45, 1165-1184. [CrossRef]

32. De Vries, S. The power of procedural policy tools at the local level: Australian local governments contributing to policy change for major projects. Policy Soc. 2021, 40, 414-430. [CrossRef]

33. Du, B.G.; Chen, L. Research on optimization path of intelligent manufacturing industry policy tools based on text analysis of 31 national policies in China. Sci. Manag. 2020, 40, 47-53.

34. Melnikov, V.V.; Karelin, I.N. Public procurement as an economic policy tool. J. Inst. Stud. 2021, 13, 100-115. [CrossRef]

35. Zengul, F.D.; Lee, T.; Delen, D.; Almehmi, A.; Ivankova, N.V.; Mehta, T.; Topuz, K. Research themes and trends in ten top-ranked nephrology journals: A text mining analysis. Am. J. Nephrol. 2020, 51, 147-159. [CrossRef] [PubMed]

36. Tseng, F.C.; Huang, M.H.; Chen, D.Z. Factors of university-industry collaboration affecting university innovation performance. J. Technol. Transf. 2020, 45, 560-577. [CrossRef]

37. Fischer, B.B.; Schaeffer, P.R.; Vonortas, N.S.; Queiroz, S. Quality comes first: University-industry collaboration as a source of academic entrepreneurship in a developing country. J. Technol. Transf. 2018, 43, 263-284. [CrossRef]

38. Kuhlmann, S. Introduction to discussion paper on 'three frames for innovation policy: R\&D, systems of innovation and transformative change'. Res. Policy 2018, 47, 1553.

39. Liu, R.; Wu, J.; Zhang, D.P.; Sha, D.C.; Wang, W.L. Themes of polies for Industry-University-Research collaborative innovation in China and its evolution. Technol. Econ. 2016, 35, 45-52.

40. Zhu, G.L.; Yang, D.P. Research on University-Industry Collaboration and policy evolvement based on patent data. Sci. Technol. Manag. Res. 2017, 37, 181-185.

41. Hsieh, H.F.; Shannon, S.E. Three approaches to qualitative content analysis. Qual. Health Res. 2005, 15, 1277-1288. [CrossRef]

42. Yang, Q.; Huang, J. Content analysis of family policy instruments to promote the sustainable development of families in China from 1989. Sustainability 2020, 12, 639.

43. Kutela, B.; Novat, N.; Langa, N. Exploring geographical distribution of transportation research themes related to COVID-19 using text network approach. Sustain. Cities Soc. 2021, 67, 102729. [CrossRef]

44. Shiau, W.L.; Dwivedi, Y.K.; Yang, H.S. Co-citation and cluster analyses of extant literature on social networks. Int. J. Inf. Manag. 2017, 37, 390-399. [CrossRef]

45. Garg, M.; Kumar, M. The structure of word co-occurrence network for microblogs. Phys. A Stat. Mech. Its Appl. 2018, 512, 698-720. [CrossRef]

46. You, C.M. Law and policy of platform economy in China. Comput. Law Secur. Rev. 2020, 39, 105493. [CrossRef]

47. Bodas Freitas, I.M.; Marques, R.A.; Paula Silva, E.M. University-industry collaboration and innovation in emergent and mature industries in new industrialized countries. Res. Policy 2013, 42, 443-453. [CrossRef]

48. Zhao, X.Q.; Li, T.E.; Dong, L.Y. Policy analysis and countermeasures of network ecological governance: Based on the perspective of policy tools. Inf. Stud. Theory Appl. 2021, 44, 23-29.

49. Lei, X.P.; Zhao, Z.Y.; Zhang, X.; Chen, D.Z.; Huang, M.H.; Zhao, Y.H. The inventive activities and collaboration pattern of university-industry-government in China based on patent analysis. Scientometrics 2012, 90, 231-251. [CrossRef]

50. Li, Y.; Wen, D.; Sun, X. Quality supervision game between government and online shopping platforms. Total Qual. Manag. Bus. Excell. 2018, 29, 1246-1258. [CrossRef]

51. Bai, X.J.; Li, Z.Y.; Zeng, J. Performance evaluation of China's innovation during the industry-university-research collaboration process-an analysis basis on the dynamic network slacks-based measurement model. Technol. Soc. 2020, 62, 101310. [CrossRef]

52. Hu, R.T. Analysis of supply side factors for the formation and resolution of overcapacity. Mod. Econ. Res. 2016, 2, 5-9.

53. Kleis, L.; Ramirez, R.V. Information technology and intangible output: The impact of IT investment on innovation productivity. Inf. Syst. Res. 2012, 23, 42-59. [CrossRef]

54. Mei, C.; Wang, X. Political incentives and local policy innovations in China. J. Chin. Polit. Sci. 2017, 22, 519-547. [CrossRef]

55. Fischer, B.B.; Schaeffer, P.R.; Vonortas, N.S. Evolution of university-industry collaboration in Brazil from a technology upgrading perspective. Technol. Forecast. Soc. Chang. 2019, 145, 330-340. [CrossRef]

56. Desmarchelier, B.; Djellal, F.; Gallouj, F. Mapping social innovation networks: Knowledge intensive social services as systems builders. Technol. Forecast. Soc. Chang. 2020, 157, 120068. [CrossRef]

57. Xu, Z.; Zhang, J.C. A study on the government's attention to scientific and technological talents since the founding of new China-based on the text analysis of the government work report (1954-2019). Sci. Sci. Manag. SET 2020, 41, 19-32. 
58. Zhu, Y. Policy agenda of Industry-University-Research collaborative innovation: A perspective of multiple streams model. J. Beijing Univ. Aeronaut. Astronaut. Soc. Sci. Ed. 2021, 34, 154-159.

59. Martinez, B.; Reaser, J.K.; Dehgan, A.; Zamft, B.; Baisch, D.; McCormick, C.; Giordano, A.J.; Aicher, R.; Selbe, S. Technology innovation: Advancing capacities for the early detection of and rapid response to invasive species. Biol. Invasions 2020, 22, 75-100. [CrossRef]

60. Singh, S.; Saxena, N.; Roy, A.; Kim, H. A survey on 5G network technologies from social perspective. IETE Tech. Rev. 2017, 34, 30-39. [CrossRef] 